\title{
Surfaces
}

\section{PRAGUE INTELLECTUALS AFTER 1989: ENACTING THEIR OWN POST-MORTEM OR CROSSING OVER THE POSTMODERN DIVIDE}

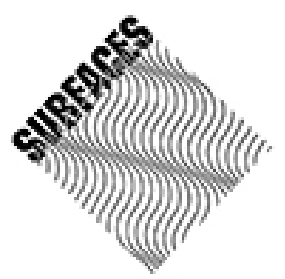

\section{Caroline Bayard}

Volume 2, 1992

ACTES DU COLLOQUE « REPENSER LA CULTURE »

ACTS OF THE CONFERENCE "RETHINKING CULTURE"

URI : https://id.erudit.org/iderudit/1065221ar

DOI : https://doi.org/10.7202/1065221ar

Aller au sommaire du numéro

Éditeur(s)

Les Presses de l’Université de Montréal

ISSN

1188-2492 (imprimé)

1200-5320 (numérique)

Découvrir la revue

Citer ce document

Bayard, C. (1992). PRAGUE INTELLECTUALS AFTER 1989: ENACTING THEIR OWN POST-MORTEM OR CROSSING OVER THE POSTMODERN DIVIDE.

Surfaces, 2. https://doi.org/10.7202/1065221ar
Résumé de l'article

Une étude de la situation culturelle des intellectuels dans la Tschécoslovaquie contemporaine.
Copyright (C) Caroline Bayard, 1992

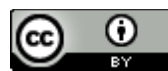

Ce document est protégé par la loi sur le droit d'auteur. L'utilisation des services d'Érudit (y compris la reproduction) est assujettie à sa politique d'utilisation que vous pouvez consulter en ligne.

https://apropos.erudit.org/fr/usagers/politique-dutilisation/ 
CONFERENCE PROCEEDINGS

"RETHINKING CULTURE"

PRAGUE INTELLECTUALS AFTER 1989:

ENACTING THEIR OWN POST-MORTEM OR CROSSING OVER THE POSTMODERN DIVIDE

Caroline Bayard

Cette conférence a été donnée au colloque

Repenser la culture

qui s'est tenu à l'Université de Montréal, les 3, 4 et 5 avril 1992.

Les organisateurs tiennent à remercier, pour leur soutien financier:

le Conseil de Recherche en Sciences Humaines du Canada

la Faculté des Arts et des Sciences, Université de Montréal

le Vice-rectorat à l'enseignement et à la recherche, Université de Montréal

le Département de Littérature comparée, Université de Montréal

Alitalia 
A study of the cultural situation of the intellectuals in contemporary Czechoslovakia.

\section{RÉSUMÉ}

Une étude de la situation culturelle des intellectuels dans la Tschécoslovaquie contemporaine.

The euphoria of the 1989 democratic revolutions is dead, not only in Germany, but also in all communist countries [...]. After the carnival, one has a hang-over.

Adam Michnik, "Correspondances",

Lettre internationale, Hiver 90-1, p. 75.

To utilize the past does not mean to perpetuate it or to return to it, but to choose and extract from it something which then becomes an integral part of our present, a stone brought to the building process which is our present. (Translation mine)

Ladislav Hejdanek "Evropa a D_jiny",

Lettre internationale, no. 1, Podzim, 1990, p. 11-12

(Translation mine).

Postmodernism is politically minimalist and a deconstructor of redemptive politics. The clown is also the antipode of the specialist. With his broken and sad smile, the clown may attempt to console us, but he will not undertake to cure us. 
Ferenc Feher, "The Status of Postmodernity"

in The Grandeur and Twilight of Radical Universalism,

1991, p. 544,48

Already the 90's seem immensely far away from what we were referring to, in November 1989 as the annus mirabilis of the century. Ralph Darhrendorf, in his famous letter Reflections on the Revolution in Europe, intended for a gentleman friend in Warsaw, thoughtfully reflected on the bewildering succession of events, as well as on the problematical developments awaiting the other Europe, when he pointed that by leaving the totalitarian fold Central European countries may also be unreflectively entering the tacky era of Casino capitalism.[1] I believe he was also trying at the time to alert his friends to the socio-economic complexities of a world where the rules of the game were considerably different from what they, as Central Europeans were expecting. When explaining to them that the West was "...by no means as rosy as you tended to paint it when we were talked", Darhendorf was not justifying the political absurdities of Central European totalitarian Regimes, nor was the speaking from an opinionated Labour or social-democratic position frequently inclined to make compromises with these Regimes (mostly for the benefit of Euro-Communism in the 70's!), but was realistically interpreting for them the intricate socio-economic developments which had taken place in the West during the preceding 50 years, while alerting them to the mirage of a few illusions they seemed susceptible to fall prey to, such as the possibility of a Third Way, or an uncritical adherence to Casino Capitalism ethics.

Darhendorf's apprehension and anxieties were indeed confirmed by the early part of this decade as well as by some of his Czech colleagues' severe assessment of the politicans' underestimation of the depth, difficulty and time required for the transformation of a society.[2] Not only the economic hardships experienced by the Vysherad Triangle countries (Czechoslovakia, Hungary, Poland), but also the violent demise of the Yugoslav federation underline the perceptiveness of Darhendorf's worse suspicions in 1990. If indeed, as political scientist Morgan Stanley[3] was to put it in a recent article, the Greater Europe 1992 also signals the year of living dangerously, where does this leave the young fledging democracies which had aroused so many hopes in Central and West European communities during the extradorinary experiences of this unforgettable annus mirabilis? 
The present paper is intended to focus specifically on the Czech experience of democracy in the early part of this decade. Precisely because Czech dissidents had played such a prominent role in the unfolding of totalitarianism, in the attentive elaboration of a civil society's alternatives and parallel networks, they constitute today an eminently pertinent area of investigation now that they are involved in the process of what, in Darhendorf's words, could be defined as the complex switch from the ethics of conviction to the ethics of responsibility.[4] I would risk that this Oxford historian may have had more than an inkling of such complexities, since as one of the most attentive observers of the first type of ethics, he was justifiably cautious in exhorting his Czech friends to practice patience and reasonableness throughout the bewildering political and economic changes awaiting them at the dawn of a new decade. Similarly, I have some reason to believe that Havel himself [1985] at a time when he was in between two jail sentences may have had a premonition of the absurdity of such a switch, when he confessed to Karel Hvi_dala; "yes, there is something deeply suspicious about an intellectual on the winning side"[5] Well, there they are now, certainly suspect, certainly in the spotlight, indubitably surrounded by all the trappings of power. The powerless are now in power.[6] And if Samuel Weber was right about his warning of yesteryear in his essay, "Politik als Beruf",[7] that to enter politics means to seal a pact with the Devil, ... then Havel is probably as qualified as various candidates to speak about that particular conundrum. The obsessive Faustian quality of his plays does betray a certain proficiency on the issue of pacts with the Devil. [8]

At present, I would like to focus on a number of documents which, for the most part, have not yet been translated into English, but which could help decipher the new roles of oppositional ex-dissidents in a culture which appears, at present, to be superlatively, though understandably, obsessed with managerial, economic as much as constitutional or judiciary decision making. In order to do so one needs to refer to three types of documents; firstly, to review the events which have modified the political fabric of the last two years, secondly, to examine articles published in $P$ itomnost and Prostor -- two among many of the intelligentsia's periodicals which have sprung up in the last 24 months in Prague -- with special attention to The Intellectuals and Power Conference organized by the latter in June 1991 [Intelekectuálové a moc][9], a two-day seminar which became a thorough deconstruction of the traditional concept of intellectual as prophet, philosopher or artist in charge of the national soul, a concept which traverses Czech history and has given rise to a powerfully influential ethos from Jan Hus to Tomá Masaryk. Thirdly, one needs to draw upon two very recent books of Havel which are not yet accessible in English, Projevy[10] -the public speeches he gave since his election to the Presidency -- and Letní P_emitání[11] (summer meditations) -- which is due to come out with Knopf early this summer. I do feel that both are relevant to the issue I want to focus on (i.e.) the role of intellectuals in a postmodern world and their redefined loci in the new European house. May be for a start, a telegraphic review of the upheavals which took place since the beginning of the Sametová Revoluce[12] could be in order. First of all, Czechoslovakia also 
became a country that changed its name and after March, 1990 called itself the Federation of Czech and Slovak Federal Republics, a modification which took over a week to enact in the newly elected Parliament of 1990 and reflected the deep ambivalence of any attempts at enunciating national self definitions.

Early in 1990, after the elections of three Parliaments, one Federal and the other two of the Czech and Slovak Republics, the formation of a Federal Government under the auspices of the Ob_ansk_Forum, it became clear that an agreement on the issue of Slovak autonomy would be particularly arduous to work out before 1992. While Havel has publicly supported a vote on Slovak autonomy by the Slovaks, it has not been possible so far for the Parliament in Bratislava to articulate a text upon which the various Slovakian political parties would agree.[13] In the context of the upcoming June elections, the national issue has been temporarily set aside and will only be dealt with by the three newly elected bodies which will preside over political decision making in Prague and Bratislava next summer.[14] To complicate matters further, since March, 1990 the newly formed Federation has had to acknowledge the enormity of the ecological nightmares, inherited from the past half century, now abundantly documented in Europe and North America.[15] On the economic front, the GNP and the inflation situation have been particularly worrisome. For the first half of 1991, the first fell by $9.2 \%$, the latter, based upon the consumer price index had risen by $49 \%[16]$, while the privatization programme has proceeded a pace since January 1, 1991,[17] featuring not only price liberalization, internal convertibility of the Koruna, but also, privatization of small businesses and land restitution to the former owners of property confiscated after the February 1948 communist takeover[18]. Nevertheless, prices have in the course of the first three months of 1992, doubled and Finance Minister, Václav Claus is being accused of copying Poland's shock therapy and of deliberately using inflation to soak up excess purchasing power. Other issues such as the split of the Ob_ank_Forum of February 1991, sometimes described as the "inevitable and amicable divorce" of the majority coalition part, which had formed the first democratically elected government in 45 years, a split theoretically designed to allow the government to concentrate on pressing economic issues and working out a constitution, has not exactly worked out this way and has indeed brought the federal government to a standstill before the June 1992[19] elections. Among other concerns, and not of the least, is the issue of the new accessibility to Secret Police files, a pressing one in any post-totalitarian state, and one that the Czechs have not satisfactorily resolved in Havel's own terms, any more than in those of the civil supporters from the Helsinki Watch Group, such as Jeri Laber whose concerns as a civil rights activist from outside Czechoslovakia deserve to be taken seriously by the present political authorities[20] (More about this later when I look at his Letni $P$ emitáni). Havel's apprehensions about the opening of those files, a choice he personally opposed but which got a narrow majority in the Federal Parliament, also remind us here of the remark made recently by the mayor of what used to be called Leningrad: 
A totalitarian system leaves behind it a minefield built into both the country's social structure and the individual psychology of its citizens. And mines explode each time the system faces the danger of being dismantled and the country sees the prospect of genuine renewal.[21]

While Sobchak's frustration primarily focuses on the situation in Russia, his metaphor, and his sobering analysis does highlight the convoluted ways in which this particular legacy has not been dealt with, by, or for the citizens of the Czech Republic. Lidové Noviny, as recently as February 1992, complained that the Commission set up to investigate the violent suppression on November 17, 1989 had exonerated the Secret Police of responsibility in this matter.[22] Damned if you do, damned if you don't could be the resentful admonition which follows land-mine defusing teams in Europe's newly elected governments.

It is interesting in this context to look at the partial transcript of the Intellectuals and Power Conference (Intelektualové a moc) of last June. A number of elected officials, Petr Pithart and Václav Havel among them, had been invited to this particular event. It should have come as no surprise to those present -- some of whom had been early Charter 77 supporters -- that neither the President of the Czech assembly nor that of the Federation found time to attend that event, but given the very serious, though remarkably differently positioned challenges which were addressed to them, in absentia, one would hope they would heed the warnings that were thus proferred by a variety of philosophers, sociologists and journalists. The conference focused on the changing role and responsibility of intellectuals in the post-November 1989 period.[23] As a concern, it was not particularly new or original. If one has been a regular reader of Lettre internationale for the past three years, that is about all one has heard about, and if one has followed Adam Michnik's or Geörgy Konrad's[24] writings on the matter, one has some notion of the hangover impression made on some intellectuals by the events of November 1989. What was unique however about the /pp. 13-14/ Prague conference, was that the notions of role and responsibility which it confronted probably signaled the only consensual denominator shared by those in attendance, though the definitions of these notions varied considerably. The epithet 'changing' was not included in the consensus. Ladislav Hejdanek, who enunciated what was the majority opinion, defined the intellectual as the one whose perennial responsibility remains to confront power, brave harsh circumstances and, most importantly, to desire truth and to accept to lose in this anxious face à face with truth which the true intellectual must accept as his or her lot. Truth shall prevail; "Pravda Vizt zit" was Jan Hus' promise to the world. Hejdanek and his colleagues would not allow anyone to forget that Czech culture leans against an impressive genealogy of philosophers and ethicists among whom are Jan Pato_ka and Emanuel Rádl[25] and that the latter's final testament; "we do not possess truth, it is truth that possesses us"[26] [ne my máme pravdu, ale pravda e má nas] has been a powerful reminder to several generations of intellectuals of both the responsibilities and the limits of human agency 
throughout history. What should strike one about this Conference is that the majority opinion, while criticizing Masaryk for trying to fuse an ideal conception of politics with the realm of the possible in the interwar years, ((i.e.) a version of eschatological utopianism), nevertheless insisted on setting this against the background of Czech history wherein intellectuals are regularly called upon to play the role of Saviour in times of emergency [nouzové rolé intelektualu v_eské politice].[27] Some nations call upon military men to perform such a feat, others upon philosophers and writers. One could call such a request; Salvation in a time of cholera. Yet, all participants agreed that because the Masarykian imbroglio was being played out for the second time in the 20th century, it was in serious need of undergoing a thorough critique. What they did not agree upon however, was the role that the 90's may be carving out for intellectuals in Central Europe.

Reading through the proceedings of that Conference as well as through the periodical $P$ itomnost [28] provides observers with a good summary of the debates presently raging in the 'second Europe' (Czechoslovakia, Poland, Hungary), of the presently intense recycling not only of the unresolved issues of the 19th century -- nationalism being foremost among them -- but also of the buried problematics of the last four centuries -- religious pluralism, the writing of History, the duties determined by an individual's conscience and the exercise of one's freedom. On top and over all of the above, if one adds the complex demons coming out of the totalitarian freezer (such as the opening of the Secret Police files which Havel's Letni $P \_$emitáni[29] consistently opposes), one has a fairly accurate grasp of the issues facing the citizens of these cultures. Most of us have followed such debates in the various European editions of Lettre internationale, Jacques Rupnik, Adam Michnik and Ferenc Feher[30] have been particularly analytical of such problems. But $P$ itomnost which has published all of the above, has also provided its readers with fascinating excavations of historical treasures (such as the making of History in the 19th Century) and the present psychic anxieties around the issues of subjective and collective identity, around one's domov.

While the spectrum of national, economic and cultural issues is wide among Czech intellectuals, I will -- at my own risk of course -- simplify it down to two main tendencies. The first one I -- as much as they --- call postmodernist. Václav B_lohradsk an exiled philosopher since 1972, who presently divides his time between a Chair of Political Philosophy in Trieste and other teaching responsibilities in Prague, as well as the editorship of $P$ itomnost, and Miroslav Petricek, the Czech translator of Derrida, are the most visible articulators of that position. A number of Havel's texts also reveal substantial affinities with such viewpoints (though those are offset by a number of eschatological elements, as well as by a strong pull towards Heideggerian paganism as I will try to show later[31]). All of the above declare themselves cured of the illusion of Redemptive politics and unwilling to look at intellectuals as spiritual guides entrusted with the community' conscience or well being [du_e]. While B_lohradsk_acknowledges that such a role is certainly called upon in times of war, foreign occupation and 
underground resistance, the 90's require, in his view, different responses and substantially distinct talents. One does not have to be heroic anymore, just patient, immensely patient to clear the rubble. A number of the writers who publish in $P$ itomnost also appear to hold similar views. As Eva Hartmannova, a social scientist and political observer puts it a thoughtful deconstruction of the foundational myths of the old Masarykian Republic of 1918[32] as well as of the powerful theologies of 19th century nationalisms seems to be in order for the 90's. Her article 'Nacionalismus', is particularly helpful in highlighting the different narratives of nationalism and the Masarykian articulation of particular ones which he successfully transformed into a highly effective foundational myth in his The Czech Question, (1884) in a way that was persuasive enough to impose its vision on the 1919 Versailles Treaty. But this narrative was also a construction, as Hartmannova insists, a careful selection, the masterful invention of a tradition. Masaryk selected Kollar, Palacky and Havlicek, even though such "traditions" were three among many possible historical narratives, so that The Czech awakeners were the creators of the modern Czech awareness and their pointing to a remote history the powerful base of an imaginary ideology, meant to mobilize broad spheres of the citizenry. It is interesting to note that Hartmannova also looks at Western social sciences and Western historiography of the last ten years as the locus of efforts which produced valuable insists and diagnoses into the notion of nationality. She recovers from such sources the idea that a nation is both made and constructed, often artificially, rather than given naturally or emerging from biological determinisms. Similarly, she is careful to note that such deduction might have been fairly threatening to the past communist regime, since the standard works on nationalism produced by West European scholars in the 70's or the 80's in this area were never made available in Czekoslovakia. Hartmannova also make it clear that studies on nationalism which had been published in the 19th century are also missing from the university archives as well as the National Library. She stresses that such issues were never discussed during the past regime, and expresses doubts about the ability of either the Right or the Left of the present political spectrum to deal with them in a reasonable manner. In her mind, the absence of any serious research into the essence of nationalism after 40 years of censorship does create a fertile ground for uncritical acceptance of the old myths based upon the concept of national identity.[33] While she does not oppose the autonomization of Czech and Slovak subjects -- which she perceives as an irreversible process at this point -- she pleads instead for a careful reevaluation of the old schemes of past nationalisms. It is interesting to see that the references upon which she bases her argumentation are primarily West European and North American examples, nation-states -- as she insists -- not based upon ethnic or cultural values, but on political ones. One could object to her that while the latter is true, nevertheless the last 30 years in Western Europe and North America have presented a few challenges against her confident assumptions about the so-called acceptability of American multi-culturalism and British tolerance of heterogeneity (to mention only a few examples), but this is another story. [34] 
While her deconstruction of the old Masarykian myths is finely tuned, Petr Prihoda's analysis is more helpful in differentiating between Narod and Stat, or Nation and State, the first being a given, a powerfully emotional and psychic given, the latter a construct, an achievement, an entity carefully negotiated through treaties, negotiations and geo-political processes. The trouble is, $\mathrm{P}$ ihoda reminds us, such terms have different meanings in different communities. To the Slovaks, States come and go, the Nation stays, such is the contemporary Slovak experience. By contrast, to the Czechs, the Nation is a construct and an achievement to cherish. Precisely because they are rushing to Europe with the idea of an efficient consumer society propagated by their confident -- but inexperienced political right -- the Czechs feel that the Slovak fascination with the notion of DOMOV is pure provincial reactionarism and a dangerous impediment to their dreams of a larger ECC. So while the Slovaks fear the homogenizing cultural influence of the ECC, the Czechs resent the Slovaks as the feeble economic partner who is spoiling their chances at finally integrating their geo-political destiny.[35] It is interesting to see that $\mathrm{P}$ ihoda faults both the Czech and the Slovak Press for having been active agents in this process, the first for not expressing the issue of identity at all, the latter for couching it in a religious and national terminology which exacerbates Czech resentment against the famous -- or rather infamous Protectorate of 1941. Could such a crisis be resolved by a referendum?

$\mathrm{P}$ ihoda doubts it, unless the Referendum would dissolve the State, an unlikely scenario at present. He envisages three options; the first, and the worst, according to him, would be the status quo option, whereby after a Referendum which silences Slovak sovereignty for a while, the common state continues, along with it problems, until the two nations grow progressively apart, and the Federation breaks up in very unhappy circumstances. In the second scenario, an incremental dissassembly of the Federation takes place through a mutual disagreement. While not easy, this process, could, in his view, still produce better neighbourly relations in the future. As for the third option, both communities heal themselves, create new spiritual representations which could accommodate a renewed dialogue. In $\mathrm{P}$ ihoda's eyes, this would be the hardest and longest option and one that would truly require, not only the cultivation of better journalism, but, also the emergence of a different world vision in each community, as well as in the majority of individuals who constitute these communities. And this is probably the scenario that Havel himself would favour.

In this context the nuances which another member of the intelligentsia, the philosopher and sociologist, Jaroslav St itecky brings to the whole problematic of identity are worth reflecting upon. To this scholar, the civic alternative (Ob_anska alterantiva) does not consist in an expansion of tolerance but in complete tolerance, period. As he perceptively puts it, a democratic identification cannot be achieved by communication alone, and what is more, this communication cannot be and should not be equated with unification alone, but rather with mediation. We can accept to be the same 
inasmuch as we are different. Acceptation and recognition of differences is our passport into the complex universe of democratic politics. And while St_itecky refers neither to Jacques Derrida, nor to Edgar Morin, there is a certain uncanniness about the commonality of ethical and political visions which emerge from his "Problem _eske Identity" as well as from recent works by French and Italian political theorists in general, on issues dealing with cultural identity, European Polity, the ethical responsibilities of communities and the political/ecological complexities of Postmodernity. Such respect for the irreplaceability of differences and differends may be the unerasable commitment of a number of European Postmodernists to the social fabric of the end of the century. Each historical period has its call as much as its divisions and its rifts when it comes to the elaboration of its pradigms. But an observer of recent developments in the Czech Polity and culture would be at fault were he/she not to heed their distinctive reminders. Two pulsions emerge from the intelligentsia; the first one, and the most visible is what I would call the Sobchak syndrome (i.e. the need to deal with the skeletons in the closet, the land-mines underground, the semislumbering monsters of the past), it signals a responsibility towards the past and proceeds from deeply felt moral obligations. The second may not be a syndrome, but it certainly operates as a powerful call, much attuned to the possibilities of tomorrow, and is sometimes impervious to the pragmatic difficulties it arouses, and an appropriate name for it could be the "Navrat do Evropy" invocation. These two pulsions are not necessarily contradictory, but each has its own agenda, expectations, needs and priorities. Both can evidently co-exist within the same individual.

The latter deductions do not imply, or suggest, that the various intelligentsias which have either returned from exile, or the dissidents who actively participated in the overthrow of the old government before agreeing to join the Obcansk_ Forum, (in some cases to become attentive critics of its policies), speak in one unified -- however tolerant! -- voice. Certainly and fortunately Czech intellectuals at present are far from agreeing on their role and responsibilities in the 90's. First of all a number of voices -- though they still represent a minority opinion - -- are asking to be heard and not only among the Czechs, to remind us that the intelligentsia's role has been grossly overvalued in the Age of Modernity, and -- more to the point -- that it was one of the tragic particpants in the building of totalitarianism. B_lohradsk_[36] is the most forceful on that score [Totalitarismus je samop_ecen_ni intelektuala] and it may be relevant to contextualize his anger as a reaction to Antonin Liehm's recent book Generation, and to Liehm's statements about intellectuals as the main victims of the Totalitarian State.[37] The second position, which is that of Liehm, founding editor of Lettre internationale, is that he and his generation had found themselves in a dark tunnel they could only wish to escape from. The Intellectuals described by Liehm were thus, not only martyrs, but also lighthouses, seers, healers, prophets, again. To this B_lohradsk_replies that, while indeed intelligensias were regularly sent to various Gulags throughout the 20th century, they, nevertheless, first of all had not been their most obvious victims, [less we forget that Stalinist repression had eliminated some 32 million peasants whom Liehm never once mentions], secondly intelligentsias 
had also, to various degrees, obligingly participated in the production number of their radiant tomorrows. B lohradsky is far from being alone in Central Europea to hold such a position. To another post-modernist, such as the Hungarian György Konrad,[38] European intelligentsia after their irrevocably and fortunately by-gone days, are now finding themselves left to their own devices in the new free market economy. Now, says Konrad, the State will step back, with more humility, -- it was high time it did anyway! -private patrons, foundations will play an increasing role, but if, in a liberal democracy, the citizenry does not need any spiritual mentors, it will still ask for good books. Are artists out of fashion, are writers shivering in the cold now no one needs them? Konrad implies that there are lean years ahead now that the price of books is already reaching astronomical proportions, now that Central European purchasing power is shrinking -- but asserts that literature will survive all the better while the collective ego of the intelligentsia will shrink. And it was high time it happened adds Konrad, thus echoing some of his West European postmodernist friends[39] (Vattimo, Lyotard, Morin).

So where does this leave European intelligentsias in the 90's? To B_lohradsk_, who sometimes sounds as if he were performing a send--up of Václav Claus, the intelligentsia is only a loose group of entrepreneurs [podnikatel] on an economic market primarily occupied by capitalists and labour unions [Kapitalisté a odbory].[40] Intellectuals are only selling certain products [vyrobek], which B_lohradsk_defines as distance [odstup], écart, a critical hiatus.[41] It is a small role - -- though an essential one -which provides a new ecological understanding and operates as an ecological sanity which entails responsibilities towards language [ekologie rozumu] in an age that can be described as the twilight of normal discourses, of binary certitudes about truth and falseness, since we have now reached the threshold of a new eloquentia where a precise metaphysical reason loses out to an empirical unmotivated one ["Dnes Kou i ur_ita epócha"],[42] a theme he developed not only at this Conference, but also in a large circulation newspaper Dnes, as recently as the end of February this year.[43] Such views may be familiar to a west European readership well versed in Lyotardian, Derridean and Batesonian writing on the end of metaphysics, or the obsolescence of notions such as progress, development and rational planning, but I am somewhat more skeptical about the receptivity of the Czech citizenry to his pleas for exploring cultural relativism in the wake of the master narratives' demise. Similarly, I am not certain that it be ready to envisage a more fluid definition of the political notions of Right-Left parties as used presently by the European Polity in general, or a democratic model of tolerance which would utilize both the energies of the Right, its nostalgia for the past, its respect for origins, and the energies of the Left, its perpetual capacities to challenge the status quo. It would seem that a Polity needs to practice democracy before engaging into a cautious deconstruction of its rewards.

When B_lohradsky comments that tolerance is not a Confederation of ghettoes, but the conscious effort to hear other voices, to accommodate 
one's idiom to their different needs and tonalities[44] as well as recognize the contribution of different political cultures and parties, he is obviously leaning against a postmodern philosophical scholarship which his contemporaries in Prague may be ready to hear but which professional politicians may not yet be ready to practice.

While I believe B lohradsk is attempting to familiarize his friends and colleagues with cultural and political perceptions from his past 20 years in an affluent, post-industrial, ecologically minded Western Europe (mostly with Lyotard, Vattimo, Derrida's texts). I am not sure how the general public who reads Dnes actually looked upon his analysis. However, I am aware that his colleagues at the Intelektualové a Moc Conference found it inappropriate to their own experience at best, sheer sophistry at worst.[45] Clearly B lohradsk is introducing a distinction between "Rationalita" and "Rozumnost" [Rationality versus understanding] based upon the necessary limits of development existing in a post-industrial universe, on a radical rethinking of the notions of property, reason, logic. But I am not convinced that he has proper access to the kind of argumentation that could convince a post-totalitarian citizenry that indeed foundationalism may be in need of being re-examined. I suspect that Havel's texts, both his recent Projevy and his Letni P_emitáni, may be more successful at this, as well as more capable to bridge the gap between the internal and external exiled communities which co-exist side by side at present and constitute the active intelligentsia [Hejdanek on the one hand, B_lohradsk on the other]. The language Havel uses has a better chance of being perceived by his old friends from Charter 77 -- Hejdanek in particular -- as something more than a hopeless hodgepodge of dangerous /pp. 25-26/ sophistry. The paradigmatic shifts which Havel introduces in his Davos speech of February 1992, or in his recent books, are, in fact, much akin to B_lohradsk_'s, but articulated in a language that allows them to be parially heard by the general public, as well as by the ex-dissidents. Part of the reason for the receptiveness which the citizenry has demonstrated toward his ideas (though patience has been seen to be thinning somewhat in 1992 as Jan Ob_man recently puts it[46]!) has to do with both the simplicity he is striving for (the best card in his deck with the general public) and his grounding of politics in a subjective site, in one's personal experience. Such a choice reflects an important reference to Rádl's and Pato_ka's[47] examples, and, as such, necessarily attracts the oppositional intelligentsia of yesteryear, especially when the latter has refused to join his government and chosen to remain its vigilant critics. Cases in point here would be Jan Urban, the Editor of Lidové Noviny and Ladislav Hejdanek a colleague of B_lohradsk_. Some fifteen odd years after the heroics of the parallel civil society of resistance[48]/, I believe Havel's postmodernist vision of the 90's may beable to reach a still appreciable segment of the electorate. Not because Czech voters identify particularly with the twilight of universals, but, rather, because they perceive Havel as, still, their best introduction to the world of European politics. The famous 'Navrat do Evropy' slogan of the 90's may be just that -- a slogan[49] -- but it still carries a lot of weight. Even if the ECC has been less than receptive to the Czech and Slovak request to be admitted into the fold, there is -nevertheless -- among the citizenry a sense that they are slowly making their 
way back into the European_"Domov".[50] While Havel's personal stand is fraught with contradictions, (how can a President who produces a discourse on the necessity of not holding on to power, surrendering to subjective intuition, trusting in human goodness while acknowledging the irrepressible power of evil upon the Earth, ever convince his electorate to give him another mandate?

Can any sensible European leader in his/her right mind run an election on the basis of such a Deconstructionist platform)? Yet Havel's Letní P_emitáni still reflected the majority opinion at this June Conference on Intellectuals and Power (i.e.: the need for intellectuals to enact the role of conscientious objectors' but in a place where they would not be trapped within the exercise of power).[51]

One of Havel's paradoxes is precisely that he does agree with such a conviction and behaves very much as the Reluctant President[52] (or as a critic of humanism still tempted by Masarykian idealism. Like the majority opinion at the Conference, Havel still wants to salvage the role of the intellectual as an important conscience of the Nation. But what makes Havel's position extremely complex, not to say irrevocably heterogeneous, is while the majority of Czech intellectuals have not really acknowledged the twilight of normal discourses and binary certitudes, he, on the other hand, has. For all his moralist underpinnings, and his leaning against Rádl, Masaryk and Pato ka, he has for a long time, identified normal discourse as senseless, objectivity as the product of a catastrophic Modernity, and Rationality as the disastrous, Faustian agent of our present woes.[53] There is a certain Heideggerian quality about a number of Havel's intellectual positions which is at odds with both his persona and his other perspectives on ecological relations, gender politics, tolerance and pluralism (much more akin to Edgar Morin's or J.F. Lyotard's than to Heidegger's)[54]. My own interpretation of such conflicting tensions within Havel's writings (i.e.: the Heideggerianism of Living in Truth[55] versus Havel's efforts at elaborating a representative, pluralistic, democratic culture both in Projevy and Letní P_emitáni) is that without reconciling them, Havel conflates the psychic currents which are running through the Central European Domov at present. On the one hand Letní $P$ emitáni reminds us that communities are the product of a certain History, $[\overline{5} 6]$ that the rich cauldron described here was also a geographical site, the centre of Europe and as a centre as he tells it, us often like a sponge by definition it absorbs it absorbs heterogeneous elements (Protestant, liberal, Jewish, Catholic, nationalist, Marxists, anti-semite, etc. which all need to be taken into account...).

If there is a minimal consensus that emerges out of the many documents I have been alluding to, it may be the need to acknowledge the pasts though what one does with them is another matter as the Parliamentary convulsions 
reveal and as Havel's own hesitancies suggest. What the Intellektualové $a$ Mo_Conference, as much as Havel's, Hejdanek's and B_lohradsk 's writings, suggest is that it would be foolish not to take stock of the complex legacy they also happen to be to products of. Hejdanek, in his own deeply theologically Protestant response to the Mayor of Leningrad's lament[57] about the exploding landmines of post totalitarian cultures, was attempting to deal with these issues, especially when he pleaded for an examination of the past that would not signal a return to it, but, rather, carefully extract only those elements that could contribute to the present edifice. Hejdanek's reference strikes me as deeply theological in that his plea is also the identification of the rejected stone as a possible corner stone,[58] but it is also one which his postmodernist colleagues may be well advised to heed (whatever Hejdanek's exasperation about postmodern ethics may be). Some Political Scientists have used the term "restauration[59] when dealing with such ecological processes, and have done so with the full knowledge of the sad negativity of such cylical repetiveness. Other approaches may be infinitely more attractive, as for instance that of Toma Venclova who, in a recent letter to Czeslaw Milosz favours: "a re-appropriation which acknowledges History's diversity"[60].

In this context it is pertinent to listen to other Central Europeans, particularly to those who have systematically explored and deconstructed the Western as such as Central European socio-political fabric. Feher Herenc and Agnes Heller,[61] who apart from their Hungarian intellectual background and their scholarly work on Luca_s and Habermas have also taught for two decades at the New York School of Social Research, appear to be able to contribute to the present Czech intellectuals' meditation on the value and pitfalls of Postmodern ethics. Both insist that recycling is not perforce conducive to absolute relativism, since, as they argue in The Postmodern Political Condition, (1988) the ideas and collective practices which are the most unlikely to be recycled are also those built on the strongest grand narrative (Marxism in this case) and the practices which have the best chance of being recycled are those which never really saw the day of their reckoning, the weak ones, the subtle petites histoires of democratic tolerance. Heller and Ferenc are also practical enough to insist that if Postmodernity is parasitic on Modernity, nevertheless, the Augean stables need to be cleaned, a recipe which could provide the three Europes with the beginning of a minimal pragmatic consensus to work out their complex legacies.[62],

Indeed, The Czechs have been good at practising an ethical bricolage of Minima Moralia vintage. They destroyed very few -- if any -- of Lenin's and Stalin's statues after 1989[63], as for the Soviet tank which bore the inscription 'liberation of Czechoslovakia by the Soviet Fatherland,'[64] it was not defaced with blood, nor hammered down to smithereens, more ecologically, it was painted PINK, at a public happening staged by members of the Parliament. Now that we are reaching the end of the millennium, Heller and Ferencs urge us, West and Central Europeans alike to recognise, that if we have given up on angels, healers, and Redemptors, we should not 
abandon on the consolations that clowns and laughter may still bring us.[65] In this sense they also confirm another European's intuition, on the eve of his 90th birthday, namely that if utopias can have their value, they can also prove literally fatal to societies and Polites. When suggesting that utopias are not only philosophically dubious but also hideously dangerous as well, Isaiah Berlin[66] is attempting to recover some of the stones of the Old European Home in an ecologically pluralistic spirit (which is not the same as a relativistic one)[67]. In this respect Berlin's exhumation of Machiavelli from the tenebrae of the History of ideas certainly interesects with B_lohradsky's[68] own musings about this Renaissance political thinker. But the difference between the two may be that the first believes in pluralism, while the latter is tempted by relativism. This more than a minor distinction and ultimately this may also be the other fine dividing line which separate Czech intellectuals today, and one which Havel is often tempted to cross, in both directions, with the cagey gentleness that is his intellectual trademark.

\section{Caroline Bayard}

McMaster University

Surface Page d'Acceuil/Home Page

[1]Ralf Darhendorf, Reflections on the Revolution in Europe: in a letter intended to have been sent to a gentleman in Varsaw (London: Chatto and Windus, 1990) p. 20.

[2]Ji_i Musil, 'Czechoslovakia in the Middle of Transition', Daedalus, Spring 1992, pp. 175-196.

[3]Morgan Stanley, "Greater Europe 1992: The year of living dangerously", Euro - Strategy, no. 14, Jan. 9, 1992. The implicit reference to Bruce Beresford's film will not escape my readers.

[4]Darhendorf 1990, opus cit., p. 8.

[5]See Václav Havel Disturbing the Peace (New York: Knopf) p. 88, original Czech ed. Dalkovy Vyslech (Praha: Edice Petlice, 1986).

[6]See Havel's famous essay: "The Power of the Powerless", in Living in Truth (London: Faber and Faber, 1987) p. 36-122. To give a few random examples about the Powerless who are now powerful; Ji_i Dienstbier and 
Oldrich Cerny went from various penitentiaries to cabinet minister positions, Foreign Affairs for Dienstbier and ministry of national security for Cerny, see Jeff Salot "Lessons from former foes" The Globe and Mail, February 8, 1992, p. D4. Martin Palous and Petr Uhl, Charter 77 dissidents became respectively Deputy Foreign Minister and Director General of the Czechoslovak News Agency, see Jeri Laber, "Witch Hunt in Prague", The New York Review of Books, April 23, 1992, pp. 5-8, on the massive changes taking place there in the 90 's.

[7]Weber is quoted by Javier Mugerza in "Ethique et responsabilité", Lettre Internationale, no. 8, Printemps 1986, p. 8-10. The text where Weber confronts such issues as ethical responsibility and politics is "Politik als Beruf".

[8]Václav Havel, Temptation, translated by George Theinor, (London, Faber and Faber, 1988). Temptation had been written in 1985 and published in a samizdat edition the same year as Pokou_eni, (Praha: Edice Petlice). See also his Redevelopment or Slum Clearance (London: Faber \& Faber, 1990), original Czech version was Asanaci (Praha: Edice Petlice, 1989).

[9]"Intellektuálové a moc: Diskuse", Prostor; Nezavisly_asopis, Cerven, 1991, p. 21-42, "Anketa na téma: intelektuálové a moc", opus cit, 127-134.

[10]Václav Havel, Projevy: Leden-Cerven 1990, Nakladatelství, Vy_ehrad, Praha, 1990. Selected portions from Projevy, translated by Paul Wilson were published in 1991 and 1992 in The New York Review of Books.

[11]Václav Havel, Letní P_emitání, (Praha: Odeon, 1991). Due to come out with Knopf, New York, later this summer, also translated by Paul Wilson.

[12]Timothy Garton Ash, The Magic Lantern: The Revolution of 1989 (New York: Random House, 1990), 1.

[13]On March 14, 1991, Havel broadcast a radio address to the country on the Slovak people which called a Referendum on Slovak Independence. The Czechs are the largest ethnic group -- about 10 million people -- but the five million Slovaks have long complained of economic and political domination by the Czechs. Several Slovak separatist parties led by the Slovak National party have swayed more moderate Slovak political elements, such as the Christian Democrats. See the March 14, 1991 rally on the 52nd anniversary (1939) of the ill-fated pro-Nazi independent state of Slovakia, World News Digest, no. 51, no. 2626, p. 224-5. President Havel has consistently contended that a Slovak declaration of sovereignty would be unconstitutional. As an alternative, he has called for a Slovak referendum on independence. See also Sophie Shihab, "Dérive de la Fédération tchécoslovaque: dérive Yougoslave ou modèle de solution pour l'Europe post communiste?", Le Monde, section hebd. Jan, 3-9, 1991, p. 4.

[14]The debate on the constitutional structures also goes beyond the CzechSlovak dissension, another key issue also being that of the status of MoraviaSilesia where the establishment of a third Republic has been raised as an option by the Movement for self-administrative Democracy in Brno. See Keesing's Record of World Events Digest, February 1991, p. 38018. 
[15]Ji_i Pehe, "The Green Movements in Eastern Europe", Report on Eastern Europe Vol. 1, no. 11, March 6, 1990, pp. 33-7. Peter Cook, "The Black Triangle: Eastern Europe gets full Marx for Disaster", The Globe and Mail, October 19, 1991, D5.

[16]See Keesing's Record of World Events, November 1991, p. 860-61.

[17]The legislation on "small-privatization" (i.e. 100,000 state owned shops, restaurants and other small businesses, was passed on October 25, 1990. The first auction was held on January 26, 1991 and hailed as a great success. See "Start of Market economic Reform", Keesing's Record of World Events, January 1991, p. 37974, also "The Issue of Dirty Money in the Privatization Process", Report on Eastern Europe, Vol. 2, no. 42, October 18, 1991, pp. 1-4.

[18]"Land Restitution", Keesing's Record of World Events, May 1991, p. 38207.

[19]See "Civic Forum Split", Keesing's Record of World Events, February 1991 , p. 38 017-18. The agreement to form separate groups was worked out on February 10, 1991, at the Presidential Residence in Lang. Václav Claus formed the Civic Democratic Party on the right, while Foreign Minister Ji i Dienstbier and the Czech Premier Petr Pithart set up the Civic Movement on the left (also referred to as the Liberal Club). Havel himself who numbered many Liberal Club supporters among his closest associates has remained outside of the conflict.

[20]"Naming of Alleged Secret Police", Keesing's Record of World Events, March, 1991, p. 38107. See in particular how a list of alleged informers even included Ivan Kavan, a Civic Forum Deputy who had lived in exile from 1968 to the 1989 Revolution. Allegations of collaboration with the dreaded Statni Bezpe nost have led to resignations and arrests of politicians and officials who have not been deemed helpful to the resolution of these differends. See "Naming of alleged Secret Police' "Keesing's Record of World Events", March 1991, p. 37107. See Jeri Laber, "Witch Hunt in Prague", opus cit.

[21]Anatoly Sobchak, For a New Russia, Free Press, 1991, p. 17.

[22]Lidové Noviny, February 15, 1992. And yet the same parliamentary commission had named on March 22, 1991, ten members of Parliament as having collaborated with the same former State Security. See "Naming of Alleged Secret Police", opus cit, p. 38107.

[23]Prostor,_erven, 1991 p. 21-42.

[24]See Adam Michnik, "Correspondances", Lettre internationale Hiver 90-91, p. 75, Geörgy Konrad, "Quelque chose est révolu", Lettre internationale, Hiver, 91-2, p.22-3.

[25]On this genealogy of philosophers and ethicists, see Havel's own comments in Letni Pr_mitáni, 1991, p. 113, see also his Disturbing the Peace, p. 134-36, 141, p. 7. 
[26]Emanuel Rádl (1873-1942) was a biologist and philosopher who published extensively on the history of biology and worked toward a synthesis of philosophy and socially responsible religion. His chief concerns were reflected in Západ a Vychod (West and East (1925)) where he proposed a nonformalized Western Christianity as a unifying philosophy. Rádl, who was also one of the most significant propagators of Masarykian philosophy, expressed the view that philosophers should accept personal responsibility to work for the good of mankind. See Dictionary of Scientific Biography, Charles Gillispie, ed., vol. XI, (New York: Scribners' 1975), p. 257-9. About Rádl's testament [or Philosophy as consolation] see Ladislav Hejdanek, "Filosof a Politicka Odpodvenost," Ceská Mysl, 1, 1991, p 6-17, particularly, p. 16-17 on Ut_chou z filosofie.

[27]The editor of Prostor (identified only as Prostor in the Round table discussion around these issues) summarizes this view in "Diskuse", Prostor, p. 34-36.

[28]The periodical $P$ itomnost provides interested readers with excellent excavations of such historical treasures of their attendant psychic anxieties, see for instance Jaroslav St itecky "Problem eské Identity", P_itomnost, 3, 1990, p. 18-19, Petr P_ihodā, Ceské Dilema; Slovaci", Pritomnōst, 10/1991, p. 1-3, Eva Hartmannova, "Nacionalismus, $P$ itomnost, 9, 1991, p. 21-2. Dusan T_e_tik, "K_est St_edni Evropy", P_itomnost 5, 1991, p. 8-9.

[29]Havel consistently and insistently articulated the concept of personal and subjective guilt rather than judicial guilt from January 1990 on. We are all collaborators, he insisted from his very first speech to the Republics ("Vsichni jsme vinní"), in "Projev k ob_anum na Novy rok", Praha, Lenda, 1990, Projevy, opus, cit, p. 11-19. See also Letni P_emitani, p. 94-8, 101-3.

[30]Jacques Rupnik, "Revolution, Restauration", Lettre Internationale, no. 31, Hiver 91-2, p. 18-20, Adam Michnik, "Correspondances: Varsovie", ibid., p. 79, Ferenc Feher, "Les visages de l'Europe", ibid., p. 14-15.

[31]On this particular score see Aviezer Tucker, 'Václav Havel's Heideggerianism' Telos, no. 85, Fall 1990, p. 63-78. For an analysis akin to Havel's affinities with Heideggerian Paganism, see also Du_an T_e_tik, K_est St_edni Evropy, opus cit, which focuses on a return, not to Europe, but, somewhere before it, well before the collapsing of European rationality, to the still more promising truth of Paganism as a foundational myth.

[32]Eva Hartmannová, 'Nacionalismus' opus cit.

[33]Ji_i Musil a prominent sociologist from the Czechoslovak Academyof Sciences is even more severe than Hartmannova when he speaks of the "deliberate Biafra of the spirit", carried on by the Husak Regime in the 80's, "Czechoslovakie in the Middle of Transition", opus cit., p. 177.

[34]Among the challenges that come to mind are the Scottish, Welsh, Basque, Catalan, Flemmish nationalisms in Western Europe (to mention only a few ...). As for North America, the convulsions of Meech Lake and the various constitutional wrangles which have taken place North of the 49th 
parallel could provide sobering exceptions to Professor Hartmannova's optimistic versions of West European so-called resolutions of these issues.

[35]Erazim Kohak's bitter comment: "While the West integrates, the East disintegrates", best exemplifies this mood of frustration and anger in "Ashes, Ashes, in Central Europe After 40 Years", Daedalus, Spring, 1992, p. 206.

[36]The real tunnel says B_lohradsky, is the overvaluation of the intellectual; "Ne tunel je prav_utom p_eceneni intelektual", Prostor, p. 26. See also Havel's bitter comments on Liehm in Disturbing the peace, p. 92-3.

[37]Ibid, p. 29 B lohradsky also quotes Kundera's description of the frightening lyricism of Reason, of its seduction with intellectuals, an apt metaphor, in his view, for Liehm's own illusions.

[38]György Konrad, "Quelque chose est révolu", op. cit.

[39]See Jean-François Lyotard, Le Tombeau de l'intellectuel et autres papiers (Paris: Galilée, 1984), Gianni Vattimo, La Societé transparente (Paris: Desclée de Brouwer, Paris 1990) [Italian ed. 1989, La Società transparente], Edgar Morin, "Une pensée faible, pour un monde faible", Lettre internationale, Printemps 1991, p.3-4.

[40]"je to odstup od bezprost_edniho v_domi", Prostor p. 26.

[41]I think it is important to note that B_lohradsky does not use Ratio or Rationalitat but rozumu which is closer to understanding, comprehending rather than to Rationalizing.

[42]Ibid.

[43]Václav B_lohradsky, 'Levice za vymírání sv_tlusek [the left at the price of the firefly], Dnes, 20, Ledna 1992, p. 7, "Levice po sta_eni sov_tsk_vlajky", [the Left after the Fall of the Soviet Union], Dnes, 28, Ledna, 1992, p. 7, 'Levice v planetarni dob_', Dnes, 30 Ledna, 1992, p. 7 [the Left and the Mother Earth].

[44]B_lohradsky is quite conscious that he is smuggling concepts from Western Europe into Czech; one language to another; "Modelem tolerance nenf konfederace mezi ghetty, ale "tra-ductio"', pa_ování smyslu za hranice na í e i a do na í fe i, in "Levice po sta ení sov tské vlajky". opus cit. B_ lohradsky also notes that Rightist and Leftist parties leave different traces or pathways, not only within the fabric of History, but also within the texture of language and semantics. Each of these pathways challenges the status quo, provides new interpretations. The Right provides cultures with a sense of nostalgia for origins, authenticity, a version of the Purgatory even, the Left, or communism, the most significant cultural and political movement of the 20th century, yearned for a renaissance, truth, authenticity, justice. See "Levice u planetární dob_, Dnes, 30, Ledna, 1992, p. 7. Interestingly enough he never really confronts the omninous rise of xenophobic forces in France and Germany in the 90's. As with Harmannova he only imports or smuggles, the best from the West and conveniently ignores a great deal. On Lester Brown's 1991 Report on the State of the World, see B_lohradsky, "Levice u 
planetárni dób, opus cit., on Borgmann, which he does not directly quote, see Borgmann's, Crossing the Postmodern Divide (Chicago: The University of Chicago Press, 1992).

[45]Hejdanek; "The intellectual as entrepreneur is only the street cleaner of the free market of imbecility" [Intelektual, Ktéry je pouze podnikatelem a dodavá svy intelekt na objednávku, vlastné jenom pro_i_tuje ten trh od blbosti]. Prostor, p. 28. On the danger of postmodern sophistry, see his article on the Philosopher's responsibility [Filosof a politicá odpodv_d_nost", in Ceska Mysl, 1 1991, p. 7.

[46]Jan Ob_man, "President Havel's Diminishing Political Influence," RFE/ FL-Research Report, Vol. 1, no. 11, March 13, 1992, pp. 18-23.

[47]Václav Havel, 'The End of the Modern Era'. Excerpted from his Davos speech to the World Economic Forum at Davos (Switzerland, Feb. 4th, 1992) re-printed in The New York Times, March 1st, 1992, p. E. 15.

[48]See also Disturbing the Peace, opus cit., p. 132-185. By Pato ka see his Essais Hérétiques (Paris: Verdier, 1975). On Pato ka's relevance to contemporary Czech thinking see Zden_k Pinc, Prostor, p. 26, specifically on the key distinction introduced by Pato_ka between the spiritual individual and the intellectual; "A de jsme ko enu toho, co vedlo Pato ku k distinkci mezo duchovnim_lov_kem a intelektualem". To which B_lohradsky replies that such Pato_ka's ethics are indeed remarkably important in times of war, or foreign occupation, but not applicable to a post-industrial, democratic society, ibid., p. 26-7. On Pato_ka's relevance to Hejdanek, see the latter's reply to $B$ lohradsky; that if -- in a sense -- the intellectual needs to be an entrepreneur, an investor [podnikatel] he/she, better remember Pato_ka's admonition about human life as "an undertaking which must necessarily fail or end in failure. Similarly Jan Hus' reminder about: 'truth shall prevail' [Pravda zvit_zi] must be taken to mean that what is human comes to pass, only truth shall prevail. "jestli_e máme v tradici heslo; "Pravda zvit_zi"; a jestli e ta pravda skute $n$ ma byt mocn jsi ne cokoliv, co jest, co je jsouci, pok to znamena, e intelektual sazi na n_co, co neni, proti tomu, co je", Hejdanek, Prostor, p. 28.

[49]Hejdanek, 'Evropa a d jiny', Lettre Internationale [Czech edition], no. 1, Podzim 1990, pp. 11-12. For a translation of this essay into a West European language see "L'Europe et l'Histoire", Lettre Internationale, Hiver 91-92, pp. 21-23. Hejdanek argues that the Czechs cannot come back to what they have never left, cannot return to a History which was not interrupted, however painful the totalitarian freeze was, he insists one cannot wilfully obliterate forty-three years of communism, a half century cannot be wished away with a pencil's stroke.

[50]The fact that the permanent location of the Council for Security and Cooperation (CSCE) in Europe has been located in Prague since February of last year, has probably had some impact on public opinion. Havel himself never fails to remind his audience, or readership, of such an achievement. See Letni P_emitáni, pp. 86-7 on the European Domov and the Czech and Slovak Federation's place in it. See also pp. 112-13. See also p. 63-8 a necessary European unification and its role in this process. See also in 
Projevy, Praha, Vy_ehrad, 1990, his Strasburg speech, pp. 114-129 and his address in honour of German President Richard von Weizsäker, pp. 79-86

[51]The conjunction of these two roles (conscientious objector/versus leader) may sometimes give rise to profoundly absurd managerial strategies. See the Conference participants' devastating irony at the expense of Petr Piethart, described as a tragi-comic example of the disastrous conflation of these two responsibilities, that of philosopher, and politician.

[52]Michael Simmons, The Reluctant President; A Political Life of Václav Havel (London: Methuen, 1991).

[53]Besides the Davos speech mentioned earlier, see also his "Politics and Conscience and 'Thriller' on the catastrophic dangers of omnipotent Reason and Rationality" in Václav Havel, Living in Truth (London: Faber \& Faber, 1987), pp. 136-163.

[54]See my, "The Intellectual in Postmodern Age: East/West Contrasts, Lyotard versus Havel", Philosophy Today, Jan. 1990, vol. 34, no. 4, p. 291-304, "Václav Havel's Irony is the Power of the Powerless", Open Letter, Fall 1991 - Winter 1992 [a special issue on Postmodern irony], p. 83-101, "Václav Havel et la fin de la Modernité: éthos, courage et exil", in La Fiction et l'Exil (Montreal: Humanitas, 1992), p. 9-36

[55]Aviezer Tucker, "Václav Havel's Heideggarianism", opus cit (see my footnote 30 ) is a provocative though partial article which selectively focuses on passages from Letters to Olga and the political essays, Living in Truth. Taken separately these do indeed confirm Tucker's vision of Havel as a conservative, reactionary ecologist. While Tucker recognizes that Havel's and Pato ka's ethics clash with Heideggarian philosophy, he fails to take into consideration the substantial evidence which traverses Havel's writings on issues such as individual rights, religious tolerance, democratic pluralism and the respect of differences inherently necessary to the functioning of political democracies. If Tucker's intuitions about the unfolding of the Ob_ansk_Forum are to be lauded, some years later, his hatchet job does not ascertain a careful scrutiny.

[56]Letni Premitani, see on the rich cauldron of Central Europe, p. 109-112.

[57]Antonin Sobchak, opus cit. See also Havel: "jsme tak trohu houbou, ktéra postupn_i soub_n_do sebe nasávala a vstrebávala nejrozmanit_j_i my_lenkové a kulturní impulsy a iniciativy, jsme místem, kde se dokonce nejdena europská iniciativa rodila i formolava", Letní P_emitáni, p. 112-3. [We resemble a little sponge which would have soaked up and absorbed different thoughts, initiatives and cultural impulsions.]

[58]"Evropa a d jiny" (1990), opus cit. For biblical references to the rejected stone which became the cornerstone, see Mark 12, 10.

[59]Jacques Rupnik, "Révolution, Restauration", Lettre Internationale, Hiver 91-2, pp. 18-21. One should note that Rupnik has an interesting suggestion to make to Adam Michnik and Polish intellectuals in this article. Michnik, according to Rupnik, unconsciously (sic) rehearses 19th Century 
problematics when he opposes democracy and national populism. In doing so, he's not necessarily more persuasive, just more repetive of the same.

[60]Toma_Venclova, quoted by Rupnik, p. 19, is writing about Vilnius/Wilno, a city which before the war, was Polish, Jewish, German, Byelorussian, and which can only re-appropriated by History, if and when its heterogeneity is identified and recognised.

[61]Feher Ferenc, Agnes Heller, The Postmodern Political Condition (New York: Columbia University Press, 1988), see ch. 1, p. 1-13, and "Europe -- an Epilogue?", p. 146-159.

[62]Feher \& Ferenc demonstrate in 1988 an optimism they may nuance with some correctives in the mid 90's. When they describe "Modernity as a state of permanent Revolution and Postmodernity as the epic of settling-in" ... it is not difficult to assume they might revise this statement. In this light, their 1988 final essay 'Europe -- an Epilogue?' may be usefully contrasted with Jacques Derrida's L'autre Cap (Paris: Minuit 1991), an essay which incidentally was read in Torino, 20 May 1990 at a Conference on European Cultural identities chaired by Vattimo, where Heller, Vladimir Bukovsky and Vittorio Strada were present. See L'Autre Cap, p. 11.

[63]See Mark Lewis, "Lenin in ruins", Canadian Journal of Social and Political Theory, vol. XV, no. 1-3, p. 1-18, specifically footnote 21 on Havel's suggestion that social realist monuments should be placed, undamaged, in a forest where trees would grow around and over them.

[64] See the amusing description of the incident by Toma_ Novak, in "Ruzovy Tank" Alternativa, no. 23, Kv_ten 1991, p. 1-16.

[65]See on the clown as a metaphor of postmodern art and Fellini's pagliaccio, Feher Ferenc, "The Status of Postmodernity" in The Grandeur and Twilight of Radical Universalism (Transaction Publishers, NJ, 1991), p. 545 .

[66]The Crooked Timber of Humanity: Chapters in the History if Ideas, ed. by Henry Hardy (London: Knopf, 1991). Of the eight essays contained in this book, see specifically, (1988) "The Pursuit of the Ideal" and the "Decline of Utopian Ideas in the West" (1988).

[67]See Conor Cruise O'Brien on this in "Paradise Lost", New York, Review of Books, April 25, 1991, p. 52-60. O'Brien sees contemporary

Deconstructions as a form of relativistic values at the end of this century. While Berlin does not refer to Deconstruction he specifically addresses the differences between relativity and pluralism in his fourth essay "Alleged Relativism in 18th Century European Thought".

[68]See B_lohradsky in Prostor, "Diskuse", opus cit., p. 29. On the Utopia of both a Leftist and Rightist variety (Klaus being a classic case of the latter) ibid., p., 40. 